\title{
DNA Polymerase Subunit Gamma-1
}

National Cancer Institute

\section{Source}

National Cancer Institute. DNA Polymerase Subunit Gamma-1. NCI Thesaurus. Code C143071.

DNA polymerase subunit gamma-1 (1239 aa, $140 \mathrm{kDa})$ is encoded by the human POLG gene. This protein plays a role in mitochondrial DNA replication. 